\title{
The Use of Human Five Senses as Models to Enhanced Music in Worship in Abeokuta, Nigeria
}

\author{
Israel Oluwagbemiga Odewole $\mathrm{e}^{1,2}$ \\ ${ }^{1}$ Centre for Advanced Theological Studies, Crowther Graduate Theological Seminary, Abeokuta, Nigeria \\ ${ }^{2}$ Visiting Academic, Department of Practical Theology, University of Pretoria, South Africa
}

\section{Email address:}

jesuoluwaobami340@yahoo.ca

\section{To cite this article:}

Israel Oluwagbemiga Odewole. The Use of Human Five Senses as Models to Enhanced Music in Worship in Abeokuta, Nigeria. International Journal of Literature and Arts. Vol. 8, No. 4, 2020, pp. 177-184. doi: 10.11648/j.ijla.20200804.11

Received: April 5, 2019; Accepted: May 27, 2019; Published: May 12, 2020

\begin{abstract}
Worship music has become a key identifier for local churches. Descriptors like "contemporary," "traditional," "blended," and "arts" are often innuendos for music styles and song repertoires. The task of planning the worship songs for a weekly gathering is not about perpetuating perceptions about your church. Worship planners should apply several principles as they select and arrange songs for worship gatherings. We commend coherence with the content of the sermon as a high priority for worship planning, since God's word is His means for making us wise rebuking, correcting, training, completing, and equipping us, the whole service should prepare believers to hear, accept, believe, love, submit to, and obey the scriptures. Songs have a unique capacity for summarizing and reinforcing Christian instruction. In order to avoid proselytizing, the model for the evaluation of the evangelical church in Abeokuta takes into account all of the elements presented in the literature as reviewed in in this article. The driving force for this model is the material that emerged in field survey, the analysis and findings. Owing to the general findings and suggestions of those that are engaging the Music in Worship, a sustainable model illustrated with the concept of our five human senses will be proposed in this article. Using the five senses to appreciate beauty is to engage all five senses - hearing, sight, tough, smell and taste - in the world of order.
\end{abstract}

Keywords: Sound Therapy, Sense, Aromatherapy, Therapeutic Touch, Music, Worship

\section{Introduction}

As the authors of The Social Psychology of Music point out, although music has many functions in human life, they are all essentially social. We use music to communicate, even when from very different backgrounds and speaking different languages. Music has the ability to trigger very powerful emotions., forming the basis of shared experiences. Music always conveys meaning, but that meaning is always situated in a social and cultural context. Meaning can never be free of context [3]. A conviction to articulate the gospel should inform the planning process. Each worship service should explicitly declare Jesus' accomplishment of salvation through his incarnation, death, and resurrection, as well as the believer's reception of salvation through faith and repentance. Make it a goal for at least lone song in the service, but preferably many more, to spell out the details of the gospel. The confession of gospel truths is what the church is built on (Matthew 16: 13-20), and so each week, the church should vocalize the core beliefs that define its existence. Few things encourage believers as much as hearing their brothers and sisters in Christ joyfully sing of their common redemption, and a loud, corporate exultation in Christ's person and power communicates the magnificence of the gospel to unbelievers.

Worship planners should prioritize the congregation's needs and interests (Philippians 2: 3-4) in their planning practices. Churches exist in unique cultural and socioeconomic contexts. Congregations will vary in their intellectual and musical gifting, and this variation should impact the choice of songs. Planners should analyze the language of potential song choices and consider whether the song communicates effectively to a particular congregation. A doctrinally rich hymn may need to be neglected if it is chockablock with archaic words. Moreover, the complexity and range of a song's melody deserve scrutiny. Worship planners need to assess the congregation's singing abilities and plan songs that will encourage rather than frustrate God's 
people. Song selection should account for the emotional responsiveness of the music. Worship should reflect the diverse emotions of biblical spirituality. If your church has experienced a tragedy, do not respond by planning a service that quickly lifts the spirits of the congregation. Acknowledge the emotional and spiritual condition of your congregation in your planning. Furthermore, intended emotional responses should play a role in planning. Sermons that push Christian toward confession and repentance deserve a worship service that encourages those same responses. More than likely, a service that begins with upbeat, celebratory tunes does not prepare Christians well for the introspection necessary for repentance leadership in this area to planning services that admonish, edify, and instruct your fellow believers. Planning worship involves many people and many details, yet when done with care and good communication, it can be a great joy.

All of the senses must appreciate the goodness of the Lord and must be redeemed for the worship of God (Navarro 2002: 89 ). The senses we are to consider as the gifts of Nature about Music as a gift from God, and though not the acquisition of our reasoning faculty, yet, in the use of them, are still subject to reason. Each of the different senses has particular sense cells that function within the sensory organs. The brain receives sensory information from five sensory organs (eyes, ears, nose, tongue, and skin for touch), with each type of sensory information traveling to its own area in the cerebral cortex for processing and storage. The author is going use these five senses to develop the proposed five sustainable model in furthering the Gospel. In Ayurveda Lifestyle Certification program, sensory impressions are considered crucial to health. Just as the food we eat creates our bodily tissues, our sensory impressions determine the quality of our thoughts and emotions. If we want greater physical and emotional wellbeing, we can use sounds, feelings, sights, tastes, and smells to balance and heal ourselves.

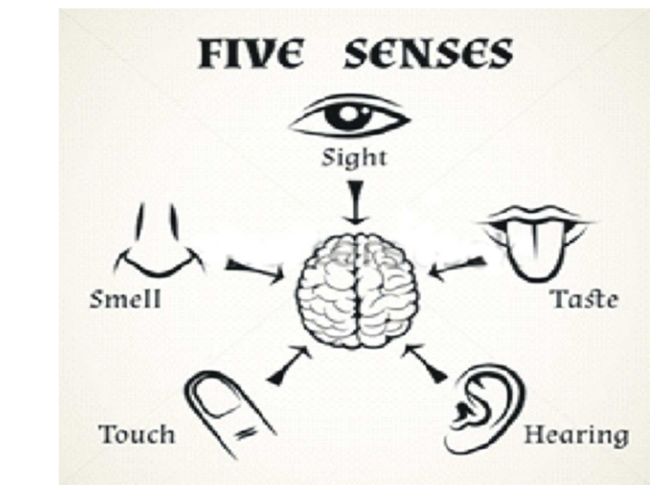

Source: www.shutterstock.com - Accessed on $04-02-2016$.

Figure 1. Five Human Senses Organ

The objects of human knowledge are innumerable; the channels by which this knowledge is conveyed are few. Among these, the perception of external things by the senses, and the information we receive from human testimony, are not the least considerable: the analogy between them is obvious. In the testimony of Nature, given by the senses, as well as in human testimony, given by information, things are signified by signs. In one as well as the other, the mind, either by original principles or by custom, passes from the sign to the conception and belief of the thing signified. The signs in the natural language, as well as the signs in our original perceptions, have the same signification in all climates and nations, and the skill of interpreting them is not acquired, but innate.

\section{The Human Five Senses as Models}

Worship music has become a key identifier for local churches. Descriptors like "contemporary," "traditional," "blended," and "arts" are often innuendos for music styles and song repertoires. The task of planning the worship songs for a weekly gathering is not about perpetuating perceptions about your church. Worship planners should apply several principles as they select and arrange songs for worship gatherings. We commend coherence with the content of the sermon as a high priority for worship planning, since God's word is His means for making us wise, as well as rebuking, correcting, training, completing and equipping us (2 Timothy 3: 14-17). The whole service should prepare believers to hear, accept, believe, love, submit to and obey the Scriptures. Songs have a unique capacity for summarising and reinforcing Christian instruction. Song choices can drown the message of the sermon, or they can amplify the word-based charge for God's people [12]. Having made these observations, the author shall proceed to give a brief description of the five human senses in relations to the summary drawn out of the five models for advancing missio Dei and the Gospel in Abeokuta and entire church at large.

\subsection{Sound Therapy Model}

At its core, music is sound, and sound is rooted in vibration. Every sound has a physiological effect. When you listen to a beautiful piece of music or inspirational words, a cascade of pleasure-producing chemicals runs through your body, supporting health and wholeness. In contrast, studies of urban environments show that people subjected to ongoing noise pollution are more likely to suffer from stress and lowered immune function. Ayurveda recognizes that music is a valuable therapeutic tool for balance and healing. The specific sounds that will benefit you most depend a great deal on your mind-body type, known as your Doshi in Ayurveda. It is also important to simply tune in to your body and discover which sounds are healing and inspiring for you. If you feel refreshed, joyful, and alert, the music is working [2]. ${ }^{1}$ This approach has been shown to be very effective at

1 Deepak Chopra, M. D., FACP, founder of The Chopra Foundation and cofounder of The Chopra Center for Wellbeing is a world-renowned pioneer in integrative medicine and personal transformation, and is Board Certified in Internal Medicine, Endocrinology and Metabolism. He is a Fellow of the American College of Physicians and a member of the American Association of Clinical Endocrinologists. - See more at: http://www.chopra.com/ccl/healingthrough-the-5-senses\#sthash.VnfUf6Rx.dpuf - Accessed on 01-02-2019. 
improving health and wellbeing. It is that sense by which we distinguish sounds, and are capable of enjoying all the agreeable charms of Music. ${ }^{2}$

David's harp had a significant impact upon the court of King Saul. This gifted composer and musician was able to go beyond what many talented musicians achieve. His music, though undoubtedly entertaining and exhilarating to the senses, possessed a unique and penetrating quality-it touched the innermost being of the listener-it reached into the very spirit of his audience. Yet what is most striking about David's harp is not merely the influence it had upon human audiences and the human spirit, but that it also had an impact over demonic beings. While the harmonic strains of other musicians might pass through the ears of evil spirits with little effect, David's music proved to be a source of power over them. The Lord demonstrated through this shepherd musician that the skillful application of melody and harmony on a musical instrument can be anointed by the Spirit of God to disperse the oppressive influence of demons.

"The Spirit of the Lord departed from Saul and an evil spirit from the Lord harassed (terrorized) him. Saul's servants then said to him, 'Behold, now an evil spirit from God is harassing you. Let our lord now command your servants to seek a man who is skillful on the harp. When the evil spirit is upon you then he shall play the harp and you will be well.' So, Saul said to His servants, 'Provide for me now a man who can play well and bring him to me.' Then one of the young men answered and said, 'Behold, I have seen a son of Jesse the Bethlehemite who is a skillful musician, a mighty man of valor, a warrior, one wise in speech and a handsome man; and the Lord is with him'... Then David came to Saul and attended him... so that it came about that whenever the evil spirit from God came to Saul, David would take the harp and play it with his hand; and Saul would be refreshed, and the evil spins would depart from him." (I Samuel 16: 14-23)

The wise and beneficent Author of Nature intended, by the formation of this sense, that we should be social creatures, and receive the greatest and most important part of our knowledge from social intercourse with each other. For these purposes we are endowed with hearing that, by a proper exertion of our rational powers, our happiness may be complete. A wealth of new studies is touting the benefits of music on mental and physical health. Listening to music was also found to be more effective than prescription drugs in reducing anxiety before surgery. ${ }^{3}$

There is growing scientific evidence showing that the brain responds to music in very specific ways. ${ }^{4}$ Playing music for kids during painful medical procedures is a simple intervention that can make a big difference. Music can help

2 Adopted from The British Academy of Sound Therapy. http://www.britishacademyofsoundtherapy.com/what-is-sound-therapy/ Accessed on $03 / 02 / 2016$

3 Psychologist Daniel J. Levitin, $\mathrm{PhD}$, who studies the neuroscience of music at McGill University in Montreal (Trends in Cognitive Sciences, April, 2013). http://www.apa.org/monitor/2013/11/music.aspx - Accessed on 03-02-2016.

4 Lisa Hartling, PhD, professor of pediatrics at the University of Alberta and lead author of the study. adult patients, too. Researchers at Khoo Teck Puat Hospital in Singapore found that patients in palliative care who took part in live music therapy sessions reported relief from persistent pain. $^{5}$

Music therapists worked closely with the patients to individually tailor the intervention, and patients took part in singing, instrument playing, lyric discussion and even song writing as they worked toward accepting an illness or weighed end-of-life issues. "Active music engagement allowed the patients to reconnect with the healthy parts of themselves, even in the face of a debilitating condition or disease-related suffering [5]." 6 "When their acute pain symptoms were relieved, patients were finally able to rest." ${ }^{7}$ Based on research in the field of Sound Therapy there are several key components of sound that may help with Depression: High frequencies activate our entire system; Constantly changing sounds activate the brain; A full range of frequencies and frequency sweeps help bring someone out of a particular stuck frequency or mood; and Binaural beat frequencies in Alpha activate the brain. They examined the effects of three types of music: a lullaby selected and sung by the baby's parents; an "ocean disc," a round instrument, invented by the Remo drum company, that mimics the sounds of the womb; and a gato box, a drum-like instrument used to simulate two-tone heartbeat rhythms. The two instruments were played live by certified music therapists, who matched their music to the babies' breathing and heart rhythms [9].

We should train our ears to appreciate only the best of the music whether contemporary or traditional. We should make it our goal to build a repertoire of only the best praise choruses, hymns, anthems, preludes, offertories, and postludes. Is the melody beautiful? Is the harmony beautiful? Does the rhythm complement the song? Does the song have enduring qualities? This is not a hymn or chorus issue. There are some hymns that are poorly written melodically and harmonically, not to mention textually. We should not be concerned with the popularity of a human or chorus but whether it honors the Lord [8].

Hearing (or audition) is the sense of detecting sound that is, receiving information about the environment from vibratory movement communicated through a medium such as air, water, or ground. It is one of the traditional five senses, along with sight, touch, smell, and taste. Both vertebrates and arthropods have a sense of hearing. In humans and other vertebrates, hearing is performed primarily by the auditory system: Sound is detected by the ear and transduced into nerve impulses that are perceived by the brain. However, when we need to decide the timing of events, we turn to our hearing. Our ears are incredibly sensitive to the rhythm of the world around us, helping us to track what happens when (and therefore judge cause and effect which is how we learn to predict the future). Music can have profound effects on our emotional state too, and it is believed that this is because of

\footnotetext{
5 Progress in Palliative Care, July, 2013.

6 Music therapist Melanie Kwan, co-author of the study and president of the Association for Music Therapy, Singapore.

7 Ibid.s
} 
the analogy between the way that music works (tone, rhythm, melodic leaps) and the way our body moves and feels in different emotional states. Music can be an instant link to a time, place or emotion. Summarily from the above, the whole of Psalm 81 is listening and hear the Lord our God is Good. In our music in worship when we think of hearing God, we probably remember situations in which we have heard the voice of God in songs, or some other form of verbal communication. No doubt we have had profound experiences of being aware of the very voice of God in various ways.

\subsection{Healing Sights Model}

Adapted from The Chopra Center, ${ }^{8}$ the visual impressions you take in have a surprisingly profound effect on your mind, body, and emotions. Watching violent movies or television shows triggers your body's stress response, creating jittery cells and suppressing the immune system. In contrast, looking at peaceful or beautiful images creates a cascade of soothing neurochemicals in the body. Surrounding yourself with images that uplift your spirit is as important for your health as nutritious food. Spending time in nature is healing for your mind, body, and soul. When you view a gorgeous sunset, look into the eyes of your beloved, or see a magnificent painting, you cultivate the power of your inner pharmacy. Of all the faculties, sight is the noblest. The structure of the eye, and its appurtenances, evince the admirable contrivance of Nature for performing all its various external and internal motions; while the variety displayed in the eyes of different animals, suited to their several ways of life, clearly demonstrate this organ to be the master-piece of Nature's works.

People in music literature commonly use the term "sightreading" generically for "the ability to read and produce both instrumental and vocal music at first sight... the conversion of musical information from sight to sound" [15]. Udtaisuk and some other authors prefer the use of the more specific terms "sight-playing" and "sight-singing" where applicable. This differentiation leaves a third, more restricted use of the term "sight-reading" for the silent reading of music without creating sound by instrument or voice. Sight-reading is the reading and performing of a piece of music or song in music notation that the performer has not seen before, also called a prima vista. Sight-singing is used to describe a singer who is sight-reading. Both activities require the musician to play or sing the notated rhythms and pitches. While both sightreading and sight-singing can be significantly challenging, in comparison to the normal way that notated music is learnedpracticing the melodies and passages individually-sightsinging is more challenging, because the musician does not have any keys, frets or valves (on keyboard instruments, guitars, and valve brass instruments, respectively) to help them obtain the correct pitches. We can see that when we look onto God, will see that the Lord id Good as the scripture records it in Psalm 119: 105 - 112.

$8 \mathrm{http}: / /$ www.chopra.com/ccl/healing-through-the-5-senses.

\subsection{Aromatherapy Model}

The most primitive of the senses, smell connects us directly with our memories, emotions, and instincts. When we smell something, we are actually absorbing some of its molecules, making aromatherapy a form of natural medicine. You can also use a process known as neuro-associative conditioning to consciously link a healing response to a given smell. First choose a favorite aroma and inhale it whenever you are feeling relaxed, calm or happy. Your body will begin to associate pleasurable feelings with the smell. Before long, just a hint of the fragrance will invoke your inner healing response. We encourage the use of local words and music to make worship more joyful and authentically African. Attention need to be given to creative writing and composition. Music should not appear to decorate the liturgy but should be regarded as integral. The arts (and music in particular) have unusually limited function in western society when contrasted with their status in other cultures or with the remoter past. For us, music is a diversion, a superficial (though pleasant) dimension to liking; it may be a background to other activities - eating, talking, even writing essays - or perhaps an occasional recreation. Even in the sphere of 'serious' music the very existence of concert halls (unknown 300 years ago) symbolizes the separateness of what goes on within. Our civilization has tended to push the arts farther and farther into a ghetto, characterized at many points by class division. It is particularly sad that so much music in Christian worship has become stylistically married to art-music and therefore associated with an educated and affluent way of life. Its use in worship has thus become divisive. $^{9}$

And which senses do we rely on most to tell us about the meaning of the world around us? Smell and taste are very important in deciding the "meanings" of potential food and drink. Even our most basic sense, taste, can tell us if something can provide energy (sweetness), protein (umami) or might poison us through toxins (bitterness) or unripe or bad food (sourness). What we eat is laden with huge consequences for our futures, and therefore rich in meaning [11]. Smell is often cited as the most powerful of the senses in eliciting emotional responses as music will produce, and there is certainly good evidence that smell can trigger earlier memories than other senses, as Marcel Proust wrote about a considerable length ${ }^{10}$. This power to trigger is linked to smell's direct connection to our emotional brain as link with music, and the fact that our first contact with a smell often defines whether it is subsequently remembered as good or bad.

Regarding the sense of smell, many Orthodox churches have something to teach us. They effectively engage the sense of smell in their worship by using incense and scented candles. In non-Orthodox Churches, this same effect can be accomplished by fresh cut flowers or by a pleasant air

9 Ibid.

10 Doctor Disruption - http://www.doctordisruption.com/sensory-branding/aresome-senses-more-important-than-others/ - Accessed on 16-05-2019. 
freshener. Yet, you must be sensitive to those who are allergic to such scents. When using scented candles, the smell should be pleasant, not overbearing. If it is too dominant, you will be focusing on the scent instead of the worship experience. In our church, the janitor puts a nice fragrance in the cleaner when he vacuums [8]. In the Old Testament time and the ancient sacrifices of burnt offerings, to present time with incense, candles, flowers and the like, scents have become connected with worship, reminding the faithful of the presence of God and symbolizing our worship rising to God. The following scriptures, Revelation 5: 8, 8: 3-4; Acts 10: 4; \& Psalm 141: 1-2 point out that throughout the history of our faith, scent has been a significant dimension of the experience of the faithful. This was evidence in the story of Cornelius in Acts 10, we are informed that the piety and holy acts of Cornelius have ascended before God as a beautiful scent.

\subsection{The Sense of Taste Model}

Ayurveda categorizes food into six tastes: sweet, sour, salty, pungent, bitter, and astringent as adapted from The Chopra Center. Each of the tastes has a unique effect on our mind-body physiology and provides the flavor that makes eating a pleasure. If you include the six tastes in a meal, you will get the nutrients you need and will feel completely satisfied and energized. If one or more of the tastes are missing from a meal, however, you may feel full but unsatisfied and find yourself snacking two hours later. Sound can enhance your meal, ${ }^{11}$ Pashman, [13] says the way food sounds has a huge effect on how much we enjoy it. Different sounds of music, or even different sound levels, have different ways of enhancing or detracting from taste experiences. As Pashman [13] noted "Research shows that when you're surrounded by very high decibel level, your taste perception goes down. So loud music means the food will have less flavor. It also it works the same in an airplane where you have a high decibel level. And that's one of the reasons why you get less taste perception on an airplane," Pashman [13] says.

Give much thought to the music of the worship service, one could note that some certain taste brings to mind specific memories from our past: persons, places, events, feelings. Again, balance is the key. Be sensitive to the congregation's musical tastes (which are usually not very high) and their attitudes, likes, and dislikes. Inform, instruct, and educate the congregation with a view toward broadening their knowledge and appreciation of hymnody, hymnology, and the nature, purpose, value, and use of church music. Thinking evangelistically with regard to the music of worship includes an awareness of the musical medium that appeals to the younger generation.

Navarro [8] remarks concerning the sense of taste in a worship experience, the best place for this is during a

11 Dan Pashman, host of WNYC's The Sporkful podcast, http://www.pri.org/stories/2019-05-17/how-music-can-affect-your-sense-taste Accessed on 17-05-2019. communion service. Many times, I have forgotten a sermon I heard but always remembered partaking of communion. There are creative ways of making the environment of the Lord's Table special. For example, in a recent communion service I led, we baked bread prior to the worship service. Both the smell and the taste of fresh-based bread made the service special. He records further that Music in worship should always come in a multitude of flavours: country, soft rock, hip-hop, rap, "unplugged," rhythm and blues, reggae, jazz and others. Yet regardless of the particular musical style, a well-crafted, cross-cultural worship song has four simple, identifiable characteristics. Songs on your list that exhibit these qualities 'PASS' the initial song selection test:

i. Personal: They relate in some way to people's everyday lives and involve their whole being, including their emotions.

ii. Attractive: They hold people's attention.

iii. Straightforward: Both Seeker Bob and Saintly Bill can understand and latch onto them quickly.

iv. Substantive: They have a thoroughly biblical message that is faithful to the whole counsel of Scripture [8].

\subsection{Therapeutic Touch Model}

Touch is fundamental to health and well-being. ${ }^{12}$ When your skin is stimulated by loving touch or massage, it releases many healing chemicals that enhance immune function, improve circulation, and promote restful sleep. "We've found compelling evidence that musical interventions can play a health-care role in settings ranging from operating rooms to family clinics" [6]. The analysis in his book also points to just how music influences health. The researcher found that listening to and playing music increase the body's production of the antibody immunoglobulin A and natural killer cells - the cells that attack invading viruses and boost the immune system's effectiveness. Music also reduces levels of the stress hormone cortisol. "This is one reason why music is associated with relaxation" [7]. While music has long been recognized as an effective form of therapy to provide an outlet for emotions, the notion of using song, sound frequencies and rhythm to treat physical ailments is a relatively new domain. ${ }^{13}$

There are many creative ways of engaging touch when worshipping together. One way is to a have a place in your worship service where the body of Christ joins hand and prays together. Another way of worshipping with the touch is your greeting time. Have people shake someone else's hand or give a hug if they know the person well enough. By having a time of greeting, passing the peace, and giving the worshippers opportunity to embrace each other, you will be providing appreciation through the touch. Another way of engaging this kind of worship is to have people clap their hands-on faster songs. This adds to the excitement in praise songs and engages the body of Christ in worshipping with

12 Adapted From The Chopra Center on http://www.chopra.com/ccl/healingthrough-the-5-senses - Accessed on the 03/02/2016.

13 Ibid. 
their physical bodies [8].

In Mashau [10] singing praises in worship is something God calls for, this forms an integral part of worship not only in this life, but also in the new life to come. God wants us to praise him through singing, clapping and dancing to the tunes of music we make for Him. We must therefore bring glory to
His name through our music. Through music, we are able to minister to one another, touch and transform lives to the glory of God [10]. We experienced God's love through tangible gifts, given to meet needs, bring comfort, or express care for others (Psalm 18: 1 - 19).

\section{Stimulus}

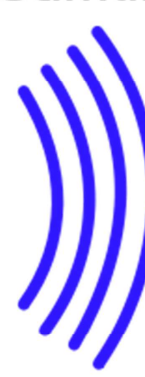

Sound

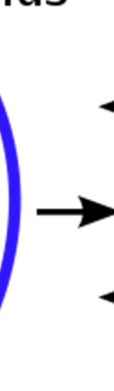

:

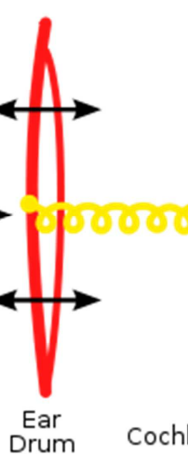

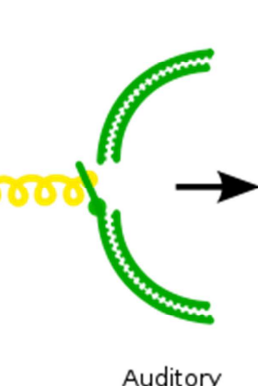

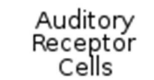

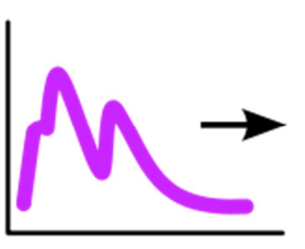

Frequency Spectrum of Hearing Response

\section{Response}

Figure 2. A schematic representation of hearing. (Blue: sound waves. Pink: auditory canal Red: ear drum. Yellow: cochlea. Green: auditory receptor cells. Purple: frequency spectrum of hearing response. Orange: nerve impulse).

Source: Computation Provides a Virtual Recording of Auditory Signaling", Public Library of Science Biology, January 2005, Volume 3, Issue 1, January 2005, Author - Original diagram by Tim Gollisch, Andreas M. V. Herz, and Public Library of Science. Converted to SVG by Iain 03:57, 12 June 2006 (UTC) http://www.newworldencyclopedia.org/entry/File: Processing-of-sound.svg - Accessed on 09-02 - 2016.

\section{Summary Drawn out of the Five Models}

Our five senses are gift to us from God, they are what makes us a living being and complete. Without each of them functioning properly we cannot offer music in worship to God, we are created with these five senses in order to offer to God good and quality music in praise and worship. When our senses function as a team of players with its different abilities then we have an unstoppable force to offer quality music in worship. If our senses are not together as a teamwork, there will be no music. These five fingers, individually they're nothing but when I curl them together like this into a single unit, they form a weapon that is terrible to behold. Each sense is important. They all play a different note in the symphony of God's concert.

Study of 1 Cor. 12: 14-19 says "Yes, the body has many different parts, not just one part. If the foot says, "I am not a part of the body because I am not a hand," that does not make it any less a part of the body. And if the ear says, "I am not part of the body because I am only an ear and not an eye," would that make it any less a part of the body? Suppose the whole body were an eye - then how would you hear? Or if your whole body were just one big ear, how could you smell anything? But God made our bodies with many parts, and he has put each part just where he wants it. What a strange thing a body would be if it had only one part! This deals with the diversity of the parts of the body and how God has made each part of the body exactly the way He desires it to be. He put each part of the body where he wanted it. Paul puts this question in the mouth of anyone who feels excluded from the body. "I don't have this certain spiritual gift. I guess I'm not part of the body of Jesus Christ." If you think about it, hands and eyes seem more important and are certainly more "glamorous" than feet and ears or intestines! He sums up the paragraph by saying "God designed this body," and Paul is speaking about the church family now.

The passage continues to say in verses 20-24 "Yes, there are many parts, but only one body. The eye can never say to the hand, "I don't need you." The head can't say to the feet, "I don't need you." In fact, some of the parts that seem weakest and least important are really the most necessary. And the parts we regard as less honorable are those we clothe with the greatest care. So we carefully protect from the eyes of others those parts that should not be seen, while other parts do not require this special care." 14 So God has put the body together in such a way that extra honor and care are given to those parts that have less dignity. In the divine design, everybody has something; but nobody has everything. The weakest parts are really the most necessary. The belly and its internal organs is covered up so it isn't visible but it does such important work!

Music must be seen in its missional context as fundamentally an enabler of fuller congregational participation. Music must serve the text of worship rather than function as an interruption or an interlude. Recovery of psalm singing in worship is an encouraging sign. In all traditions, music plays a key role in determining the flow and pace of worship and this is not a question of playing any old music, or singing any old song, to pass the time as discussed in chapter four. Whether classical or popular, congregational

141 Corinthians 12: 14-26. 
song and instrumental music should aim to be one or more of the following according to the book "Praying Twice" by Brian Wren;

i. Formative - shaping and modelling our faith as it tells a story within the whole story of God in Christ and draws us into the drama of God's saving love;

ii. Transformative - moving us from isolation to belonging, indifference to interest to conviction, and conviction to commitment;

iii. Cognitive, giving us something to ponder and think about;

iv. Educational - teaching us something we didn't know about the Bible, the Church and Christian faith;

v. Inspirational - lifting us out of ourselves into hope, joy and peace [16].

The followings are the filters we should have in place as we screen and select music for the purpose of congregational worship? Based on Puls [14] the researcher wants to give three plus one filters that he and the researcher have found useful in selecting music for worship:

i. Is it truthful?

ii. Is it suitable?

iii. Is it authentic? and

iv. Is it Missional as well?

The appropriate issue is not personal preference or even a tolerable truce, but rather discovering the cultural form (musical style) that the most people in your context can give glory and honor to God through praise and worship. Now, here is why the researcher differs slightly with those who think that having different styles might be a problem. Simply put, when you are driven by mission, not preference, you might find more than one approach appropriate. That's already obvious in one way-if people speak English and Yoruba in the community, you might need a service for each language. But, there also might be cultural differences (or even generational differences) where a church on mission might very well want to have two services with different approaches.

So, after you understand your cultural context, you may see missional benefits to additional worship services with different musical styles. There may not be an expression of worship that simultaneously relates well to both of those groups of people. Ethnic, linguistic, and even generational issues may initially hinder them from being able to worship using the same forms. We are Christ's witnesses. He sent the Holy Spirit to empower us to be his witnesses - but our witness is a whole-life witness - to all of the senses: hearing, taste, sight, feeling, smell. As his witnesses, the challenge is to grow to be a complete witness.

Puls [14] concludes that neither view is true, helpful or acceptable. We appreciate and benefit from great preachers and great messages from the past-but at the same time we continue to preach and write new sermons, instructing the people of our day in the truth of God's Word. We are enriched by the insightful, deep prayers of saints of past, such as the Puritans - but at the same time, we keep praying, voicing to God the concerns of our day, the cries of our hearts in our words. We must strive for this balance in our music as well, enjoying the fruits of our heritage in church music, and adding our own new song to God's praise through the ages.

\section{Conclusion}

From this study, the article discovered that music has the potential to energize worship where people come to view the majesty and holiness of God in new ways. African worship styles, for example, are known for their celebrative character, they most readily contribute to the joyful, festive occasions in the church [1]. Music in worship in Abeokuta, on the other hand, is elegantly slow and measured with every gesture densely packed with symbolic significance. Subtle gestures, such as movement of the eyes and careful hand positions, engender meditation and reflection. When thoughtfully combined with sound theological lyrics, they have the potential to evoke theological reflection that expands the church's expression of faith. As the singer proclaims a call to respectful worship of God, her slow elegant movements should underline the depth of her statement. As we use our five senses maximally in music in worship, we develop "dosable" and "prescriptible" music therapy and music as medicine protocols that serve specific neurologic functions and attend to deficits that may result from many of these neurologically based conditions. Rather than viewing music only as a cultural phenomenon. The content of the song text should profoundly embodied and visualized in ways that stimulate honoring God in majesty and holiness. Thus, the dynamics of reflexivity at work in Christian music will provide new theological pathways for understanding God in today's contemporary society. It will also cultivate intentional hearing of the biblical narrative in ways that evoke revitalization of our Christian faith. Missional worship songs will also foster learning to praise God in the midst of suffering.

\section{References}

[1] Barz, G. 2006. Dancing the Drama and Singing for Life: On Ethnomusicology and Music Therapy. New York: Routledge.

[2] Deepak Chopra, M. D. 2019. Healing Through the 5 Senses.

[3] Hargreaves D. J. and North A. C., 2015. The Social Psychology of Music, Oxford University Press.

[4] Hartling, L, professor of pediatrics at the University of Alberta and lead author of the study.

[5] Kwan, M., 2010. Music Therapists' Experiences with Adults in pain: Implications for Clinical Practice in Qualitative Inquiries in Music Therapy Volume 5, Barcelona Publishers.

[6] Levitin, D. J. 2007. This is Your Brain on Music, Plume/Penguin.

[7] Levitin, D. J., 2013. Trends in Cognitive Sciences. http://www.apa.org/monitor/2013/11/music.aspx - Accessed on $03-02-2019$. 
[8] Navarro, J. L., 2002. A Little Bit of Madness.

[9] Novotney, A., 2013. Music as Medicine.

[10] Mashau T. D. 2013. Coming back to the Heart of Worship: The hour of true and acceptable worship in the African city. Parow, South Africa: Acad SA Publishing.

[11] Minsky, L. and Fahey, C., 2017. Audio Branding: Using Sound to Build Your Brand. Kogan Press.

[12] Odewole, I. O. O, 2016 Missional character of Music in Worship: A Study of Select Churches in the Metropolitan City of Abeokuta, Nigeria. Unpublished Dissertation.
[13] Pushman D., 2014, Eat More Better: How to Make Every Bite More Delicious Kindle Edition, Simon \& Schuster.

[14] Puls K. 2007, Music and the Church Finding Our Voice in Worship, Music and the Church Founders Journal Vol; 67.

[15] Udtaisuk, D. 2005, A Theoretical Model of Piano Sight playing components, Dissertation presented to University of Missouri-Columbia.

[16] Wren, B. 2000. Praying Twice: The Music and Words of Congregational Song. Louisville, KN: Westminster John Knox. 